\title{
SINERGISITAS PERAN DAN TANGGUNG JAWAB ADVOKAT DAN NEGARA DALAM PEMBERIAN BANTUAN HUKUM CUMA-CUMA
}

(Synergy of Roles and Responsibilities of Advocates and State in Giving Legal Aid for Free)

\author{
Ade Irawan Taufik \\ Badan Pembinaan Hukum Nasional - Kementerian Hukum dan HAM \\ Jl. Mayjen. Sutoyo No. 9, Cililitan Jakarta Timur \\ Email: adetaufik@bphn.go.id / ade_irawancute@yahoo.com \\ Naskah diterima: 25 April 2013; revisi: 26 April 2013; disetujui: 27 April 2013
}

\begin{abstract}
Abstrak
Dalam mewujudkan prinsip-prinsip negara hukum, advokat diwajibkan memberikan bantuan hukum bagi orang atau kelompok miskin, namun pada kenyataanya kewajiban advokat dalam memberikan bantuan hukum cuma-cuma terdapat banyak kendala dalam prakteknya, oleh karena itu diperlukan campur tangan negara. Permasalahannya adalah bagaimana konsepsi bantuan hukum yang selama ini terjadi dan bagaimana sinergisitas arah bantuan hukum yang berpihak pada masyarakat miskin dan bagaimana sinergisitas peran negara dan advokat dalam pemberian bantuan hukum cuma-cuma bagi orang atau kelompok miskin. Dengan menggunakan metode penelitian yuridis normatif dapat disimpulkan bahwa konsepsi bantuan hukum yang terjadi selama ini yang bersifat individual dan konvensional dengan pengaturan yang bersifat parsial dan tidak tersistem sehingga membawa pada suatu kondisi belum terwujudnya suatu perubahan sosial yang berkeadilan dan kesadaran hukum masyarakat serta mudahnya akses untuk mendapatkan keadilan tersebut. Peran negara hadir dalam membentuk regulasi dalam bentuk UU Bantuan Hukum 2011, yang memberikan suatu konsep baru bantuan hukum. Keberadaan UU Bantuan Hukum semakin menguatkan peran advokat dalam memberikan bantuan cumacuma, sehingga peran dan kewajiban advokat yang diatur dalam UU Advokat 2003 dapat bersinergi dengan peran negara dalam menyelenggarakan bantuan hukum sebagaimana diatur dalam UU Bantuan Hukum 2011.
\end{abstract}

Kata kunci: advokat, bantuan hukum, akses keadilan, sinergi

\section{Abstract}

In realizing the principles of the rule of law, advocates were oblige to provide legal assistance to people or the poor, however the liability of advocates in giving free legal aid encounter many obstacles in practices, therefore, the intervention of state were required. The problem is the conception of legal aid that occurs and how is the synergy between advocates and states in giving a free legal aid and pro-poor legal aid. By using the normative research method, it can be concluded that legal aid conception occurred during this time is individualized and conventional with partial and unsystemized setting lead to a condition of unestablished just social change and public awareness as well as easy access to justice. The Role of states presents by establishing the regulation in form of Legal Aid Act 2011, which provides a new concept of legal aid. The existence of Legal Aid Act strengthens the role of advocates in providing free assistance, so that the roles and responsibilities set out in the Advocate Act 2003 can be synergized with the role of the state in legal aid as set out in the Legal Aid Act 2011.

Keywords: advocate, legal aid, access to fairness, sinergy 


\section{A. Pendahuluan}

Dalam negara hukum, negara mengakui dan melindungi hak asasi setiap individu tanpa membedakan latar belakangnya, sehingga semua orang memiliki hak untuk diperlakukan sama di hadapan hukum (equality before the law). Persamaan di hadapan hukum harus diartikan secara dinamis dan tidak diartikan secara statis, artinya, apabila ada persamaan di hadapan hukum bagi semua orang maka harus diimbangi pula dengan persamaan perlakuan (equal treatment) bagi semua orang. Jika ada dua orang bersengketa datang ke hadapan hakim, maka mereka harus diperlakukan sama oleh hakim tersebut (audi et alteram partem). Persamaan di hadapan hukum yang diartikan secara dinamis ini dipercayai akan memberikan jaminan adanya akses untuk memperoleh keadilan (access to justice) bagi semua orang tanpa membedakan latar belakangnya.
Menurut Aristoteles, keadilan harus dibagikan oleh negara kepada semua orang, dan hukum yang mempunyai tugas menjaganya agar keadilan sampai kepada semua orang tanpa kecuali. Apakah orang mampu atau fakir miskin, mereka sama untuk memperoleh akses kepada keadilan. ${ }^{1} \mathrm{Hal}$ tersebutlah yang menjadilandasan konstitusional $^{2}$ pembentukan Undang-Undang Nomor 18 Tahun 2003 tentang Advokat ${ }^{3}$ dan juga Undang-Undang Nomor 16 Tahun 2011 tentang Bantuan Hukum. ${ }^{4}$

Dalam usaha mewujudkan prinsip-prinsip negara hukum tersebut dalam kehidupan bermasyarakat dan bernegara, peran dan fungsi advokat $^{5}$ sebagai profesi yang bebas, mandiri dan bertanggung jawab merupakan hal yang penting, disamping lembaga peradilan dan instansi penegak hukum seperti kepolisian dan kejaksaan. Melalui jasa hukum yang diberikan, advokat menjalankan tugas profesinya demi

Frans Hendra Winarta, "Paradigma Bantuan Hukum Sekarang Harus Banting Setir," www.hukumonline.com (diakses tanggal 09 Februari 2009).

2 Di dalam Pasal 27 ayat (1) Undang-Undang Dasar Negara Republik Indonesia Tahun 1945 (UUD NRI 1945), ditegaskan bahwa segala warga negara bersamaan kedudukannya di dalam hukum dan pemerintahan dengan tidak ada kecualinya, kemudian di dalam Pasal 28D ayat (1) UUD 1945 ditegaskan pula bahwa setiap orang berhak atas pengakuan, jaminan, perlindungan, dan kepastian hukum yang adil serta perlakuan yang sama dihadapan hukum. Lihat juga Penjelasan Umum dari UU Advokat 2003 dan UU Bantuan Hukum 2011.

3 Undang-Undang Nomor 18 Tahun 2003 tentang Advokat (Lembaran Negara Republik Indonesia Tahun 2003 Nomor 49, Tambahan Lembaran Negara Republik Indonesia Nomor 4288). Selanjutnya dalam tulisan ini disebut "UU Advokat 2003".

4 Undang-Undang Nomor 16 Tahun 2011 tentang Bantuan Hukum (Lembaran Negara Republik Indonesia Tahun 2011 Nomor 104, Tambahan Lembaran Negara Republik Indonesia Nomor 5248). Selanjutnya dalam tulisan ini disebut "UU Bantuan Hukum 2011".

5 UU Advokat 2003 mendefinisikan advokat adalah orang yang berprofesi memberi jasa hukum, baik di dalam maupun di luar pengadilan yang memenuhi persyaratan berdasarkan ketentuan undang-undang ini. Dalam Black's Law Dictionary, advokat (advocate) didefinisikan sebagai "a person who assists, defends, pleads, or prosecutes for another" (Bryan A. Garner, Black's Law Dictionary, Abridged 9 ${ }^{\text {th }}$ Edition (St. Paul, MN: Thomson Reuters, 2010), hlm. 49). Advokat merupakan padanan kata dari kata 'advocaat' (Belanda), yakni seseorang yang telah resmi diangkat untuk menjalankan profesinya setelah memperoleh gelar meester in de rechten (Mr.). Akar kata advokat berasal dari kata latin yang berarti membela. Dalam perkembangannya ditemui inkonsistensi penyebutan, misal dalam Undang-Undang Nomor 14 Tahun 1970 tentang Ketentuan Pokok Kekuasaan Kehakiman dan UndangUndang Nomor 2 Tahun 1986 tentang Peradilan Umum, menggunakan istilah 'Penasihat Hukum', namun dalam praktiknya digunakan istilah 'Pengacara'. Lebih lanjut lihat Luhut M.P. Pangaribuan, Advokat dan Contempt of Court, Suatu Proses di Dewan Kehormatan Profesi (Jakarta: Djambatan: 2002), hlm. 6, lihat juga Pusat Studi Hukum dan Kebijakan Indonesia, Advokat Indonesia Mencari Legitimasi, Studi Tentang Tanggung Jawab Profesi Hukum di Indonesia (Jakarta: PSHK, 2001), hlm. 55-75. 
tegaknya keadilan berdasarkan hukum untuk kepentingan masyarakat pencari keadilan, termasuk usaha memberdayakan masyarakat dalam menyadari hak-hak fundamental mereka di depan hukum. ${ }^{6}$ Demikian mulianya profesi advokat tersebut, sehingga advokat dijuluki sebagai "officium nobile" atau "nobel profession", artinya profesi yang mulia dan terhormat. ${ }^{7} \mathrm{Hal}$ ini karena advokat diwajibkan melakukan pembelaan kepada semua orang tanpa membedakan latar belakang ras, warna kulit, agama, budaya, sosio-ekonomi, kaya/ miskin, keyakinan politik, gender dan ideologi. ${ }^{8}$

Kewajiban membela dan memberikan bantuan hukum bagi orang atau kelompok miskin oleh profesi advokat sejalan dengan prinsip justice for all dan persamaan di hadapan hukum dan hak untuk didampingi oleh advokat tanpa kecuali. Pembelaan bagi orang atau kelompok miskin diperlukan dalam suasana sistem hukum pidana yang belum mencapai titik keterpaduan (integrated criminal justice system). Seringkali tersangka atau terdakwa yang miskin, karena tidak tahu hak-haknya sebagai tersangka atau terdakwa disiksa, diperlakukan tidak adil, atau dihambat haknya untuk didampingi advokat. Penegak hukum belum bekerja menerapkan due process law (proses hukum yang adil) yang memperhatikan hak-hak tersangka atau terdakwa. ${ }^{9}$
Sangat pentingnya prinsip due process law dan equality before the law dalam mewujudkan prinsip justice for all tersebut di atas, maka bantuan hukum merupakan hak mutlak atau hak asasi yang melekat pada setiap individu manusia, sehingga advokatlah yang sangat berperan, baik dari kompetensi maupun kewenangan dalam menjalankan fungsi bantuan hukum tersebut. Oleh karena perannya tersebut, maka negara mewajibkan advokat untuk memberikan bantuan hukum bagi orang atau kelompok miskin atau tidak mampu secara ekonomi.

Kewajiban advokat dalam memberikan bantuan hukum bagi orang atau kelompok miskin tersebut secara cuma-cuma ditegaskan dalam Pasal 22 ayat (1) UU Advokat 2003, yang menyatakan bahwa advokat wajib memberikan bantuan hukum secara cuma-cuma kepada pencari keadilan yang tidak mampu. ${ }^{10}$

Oleh karena jenis sanksi yang kurang kuat dan penegakansanksiyang tidak tegasoleh organisasi advokat, maka dalam perkembangannya ketentuan kewajiban pemberian bantuan hukum secara cuma-cuma tersebut masih dianggap pekerjaan selingan yang tidak mempunyai makna dan bahkan memandang bantuan hukum sebagai sebuah "amal profesi". Frans Hendra Winata mengatakan bahwa pemberian bantuan hukum bagi masyarakat miskin sebagai penegakan HAM dan bukan belas kasihan,

Lihat Penjelasan Umum UU Advokat 2003.

Todung Mulya Lubis, Catatan Hukum Todung Mulya Lubis, Mengapa Saya Mencintai Negeri Ini? (Jakarta: Kompas Media Nusantara, 2008), hlm. 102.

8 Frans Hendra Winarta, Bantuan Hukum: Suatu Hak Asasi Manusia Bukan Belas Kasihan (Jakarta: Elex Media Komputindo, 2000), hlm. 94. Di dalam Pasal 18 UU Advokat 2003 ditegaskan pula bahwa Advokat dalam menjalankan tugas profesinya dilarang membedakan perlakuan terhadap Klien berdasarkan jenis kelamin, agama, politik, keturunan, ras, atau latar belakang sosial dan budaya.

9 Ibid., hlm. 97.

10 Peraturan pelaksana ketentuan Pasal 22 ayat (1) UU Advokat 2003 baru terwujud setelah lima tahun berlakunya UU Advokat 2003, yaitu diatur melalui Peraturan Pemerintah Nomor 83 Tahun 2008 tentang Persyaratan dan Tata Cara Pemberian Bantuan Hukum Secara Cuma-Cuma (untuk selanjutnya dalam tulisan ini disebut "PP Bantuan Hukum 2008"). 
sehingga cara pandang yang keliru tersebut menjadi alasan mengapa proses pelembagaan bantuan hukum berjalan sedemikian tersendat dan tidak kunjung mendatangkan harapan untuk bisa menjadikannya sebagai gerakan kolektif. Jika cara pandang tersebut terus digunakan, tanpa diiringi upaya mentransformasikannya sebagai komitmen perjuangan dan identitas bersama, akan berimplikasi langsung pada: (i) senjangnya distribusi kesempatan; (ii) miskinnya kualitas bantuan hukum karena dilakukan tanpa landasan idealisme yang memadai; (iii) dan semakin menjauhnya posisi advokat dari penerimaan serta dukungan publik. ${ }^{11}$

Pada umumnya program bantuan hukum yang dijalankan oleh organisasi advokat masih mendasarkan pada sifat kerelaan dari para pengurus program bantuan hukum dari organisasi advokat tersebut, dan belum menjadi suatu gerakan masif dari bergeraknya organisasi advokat dengan melibatkan para anggota dari organisasi advokat tersebut. Meski pada saat yang sama Kode Etik Advokat telah mewajibkan seorang advokat untuk memberikan bantuan hukum kepada orang atau kelompok apabila diminta. Masalah tersebut berdampak bagi orang atau kelompok masyarakat miskin yang membutuhkan akses terhadap keadilan, karena begitu banyaknya perkara-perkara hukum yang menyangkut orang atau kelompok masyarakat miskin, namun organisasi advokat sebagai penyedia layanan bantuan hukum ternyata masih memiliki kapasitas yang minimal untuk menyediakan layanan bantuan hukum bagi orang atau kelompok masyarakat miskin. ${ }^{12}$
Pemberian bantuan hukum secara cuma-cuma dalam perkembangannya pun memperlihatkan kendala dan kemunduran, terutama biro bantuan hukum yang didirikan di perguruan tinggi, yaitu, konsentrasi advokat yang terpecah (antara tugas mengajar sebagai dosen dan tugas sebagai advokat); biro bantuan hukum di perguruan tinggi bersifat "non profit oriented", sedangkan tingkat penghasilan dosen tergolong rendah; keterbatasan pendanaan; profesionalitas tenaga advokat di biro bantuan hukum di perguruan tingginegeri; dan kurangnya kepercayaan masyarakat. ${ }^{13}$

Selain hal tersebut di atas, pemberian bantuan hukum cuma-cuma oleh advokat dalam perkembangannya pun semakin tergerus karena etos perjuangan advokat Indonesia sudah lama hilang dengan komersialisme dan konsumerisme. Kue keadilan diberi "tarif", tergantung besarannya sehingga keadilan menjadi komoditas yang harganya tergantung permintaan dan penawaran. ${ }^{14}$ Keadaan tersebut pun sejalan dengan apa yang digambarkan oleh Satjipto Rahardjo, bahwa perkembangan bantuan hukum sudah mendekati sebuah "industri hukum", artinya para profesional (advokat) lebih menjalankan bisnis daripada bantuan terhadap mereka yang ditimpa kesusahan. Bantuan hukum sudah berkembang menjadi sebuah korporasi besar yang melibatkan praktik dalam bentuk unit-unit yang besar dan jasa pelayanan hukum dilihat sebagai produk yang dijual, sehingga sudah seperti bisnis. ${ }^{15}$

Harapan ke depan adalah adanya kondisi dan dorongan yang kuat terhadap peran dan

\footnotetext{
Frans Hendra Winarta, Bantuan Hukum: Suatu Hak Asasi Manusia Bukan Belas Kasihan, Op.Cit., hlm. 63.

12 Anggara, "Organisasi Advokat dan Program Bantuan Hukum di Indonesia", http://anggara.org/2011/04/12/ organisasi-advokat-dan-program-bantuan-hukum-di-indonesia/ (diakses tanggal 14 Maret 2013).

13 Frans Hendra Winarta, Bantuan Hukum: Suatu Hak Asasi Manusia Bukan Belas Kasihan, Op.Cit., hlm. 51.

14 Todung Mulya Lubis, Op.Cit., hlm. 103.

15 Satjipto Rahardjo, Penegakan Hukum Progresif, (Jakarta, Penerbit Buku Kompas, 2010), hlm. 181.
} 
tanggung jawab advokat dalam memenuhi kewajibannya dalam memberikan bantuan hukum cuma-cuma, namun tidak semua advokat mengabaikan kewajibannya tersebut. Masih banyak terdapat advokat baik secara individual maupun secara kolektif dalam suatu lembaga hukum yang tetap gigih dalam menjalankan fungsi bantuan hukum cuma-cuma, namun dengan kondisi keterbatasan pendanaan yang kurang atau keterbatasan sumber daya manusia (advokat) yang tidak tersebar merata di seluruh pelosok Indonesia, memaksa bahwa kondisi ini tidak semata-mata harus ditanggung oleh advokat itu sendiri.

Dengan melihat kondisi perkembangan tersebut, maka beban tanggung jawab pemberian bantuan hukum secara cuma-cuma tidak dapat ditanggung sendiri oleh advokat, sehingga peran negara sangat dibutuhkan dalam mewujudkan bantuan hukum. Negara secara konstitusional menjamin hak konstitusional setiap orang untuk mendapatkan pengakuan, jaminan, perlindungan, dan kepastian hukum yang adil serta perlakuan yang sama di hadapan hukum sebagai sarana perlindungan hak asasi manusia, sehingga negara bertanggung jawab dalam pemberian bantuan hukum bagi orang miskin sebagai perwujudan akses terhadap keadilan.

Selain hal tersebut, pemerintah Indonesia sat ini telah meluncurkan Strategi Nasional Akses terhadap keadilan dalam rangka pemberian akses hukum kepada masyarakat miskin dan terpinggirkan yang menekankan desakan untuk melakukan reformasi keadilan pada semua bidang kehidupan yang mendorong perubahan posisi Indonesia yang lebih baik untuk mempromosikan hukum, keadilan dan hak asasi manusia bagi masyarakat miskin dan terpinggirkan. Strategi Nasional Akses terhadap Keadilan terfokus pada delapan area permasalahan di Indonesia, diantaranya yaitu Bidang Reformasi Hukum dan Peradilan; Bidang Bantuan Hukum; dan Kelompok Masyarakat Miskin dan Terpinggirkan. Sehingga dalam rangka pemberian akses hukum, pemerintah mempunyai peranan penting terutama dalam pemenuhan hak setiap orang atas bantuan hukum. Namun, upaya pemerintah untuk memberikan bantuan hukum kepada masyarakat miskin dan terpinggirkan belum optimal dan tepat sasaran. ${ }^{16}$

Penyatuan dua kekuatan dan tanggung jawab, negara dan advokat dalam pemberian bantuan hukum cuma-cuma adalah suatu keniscayaan dalam mewujudkan prinsip justice for all, sehingga dalam penelitian ini akan sangat menarik untuk mencari bentuk suatu konsep yang ideal dari bantuan hukum sebagai upaya dapat memetakan bentuk kekuatan yang dihasilkan oleh negara dan advokat sehingga dapat disinergikan dalam upaya pemberian bantuan hukum cuma-cuma kepada orang atau kelompok miskin.

\section{B. Permasalahan}

Dari uraian latar belakang permasalahan tersebut, dirumuskan permasalahan sebagai berikut:

1. Bagaimana konsepsi bantuan hukum yang selama ini terjadi dan bagaimana sinergitas arah bantuan hukum yang berpihak pada masyarakat miskin?

16 Peraturan Presiden Nomor 5 Tahun 2010 tentang Rencana Pembangunan Menengah Nasional (RPJMN) Tahun 2010-2014: Lampiran Buku II Memperkuat Sinergi Antar Bidang Pembangunan, Bab VIII Hukum dan Aparatur. 
2. Bagaimana sinergitas peran negara dan advokat dalam pemberian bantuan hukum cuma-cuma bagi orang atau kelompok miskin?

\section{Metode Penelitian}

\section{Tipe Penelitian}

Untuk menjawab rumusan permasalahan, metode penelitian yang digunakan dalam penelitian ini adalah yuridis normatif. Metode penelitian hukum yuridis normatif pada dasarnya meneliti kaidah-kaidah hukum dan asas-asas hukum. ${ }^{17}$ Soerjono Soekanto dan Sri Mamudji ${ }^{18}$ menyatakan bahwa penelitian hukum normatif atau penelitian hukum kepustakaan merupakan penelitian hukum yang dilakukan dengan cara meneliti bahan pustaka atau data sekunder, yaitu bahan hukum primer, sekunder dan tersier. Penelitian yuridis normatif juga dimaksudkan sebagai penelitian hukum yang mengkaji hukum tertulis dari berbagai aspek teori, sejarah, filosofi, perbandingan, struktur dan komposisi, lingkup dan materi, konsistensi, penjelasan umum dan pasal demi pasal, formalitas dan kekuatan mengikat suatu undang-undang, serta bahasa hukum yang digunakan. ${ }^{19}$ Penelitian normatif dapat juga disebut penelitian hukum doktrinal, yang bertujuan untuk menemukan jawaban yang benar dengan mendasarkan pada preskripsi-preskripsi hukum yang tertulis dan juga ajaran atau doktrin, ${ }^{20}$ dan lebih cenderung bersifat kualitatif (tidak berbentuk angka) berdasarkan data sekunder. ${ }^{21}$

\section{Teknik Pengumpulan Data Penelitian}

Teknik pengumpulan data penelitian dilakukan melalui penelitian kepustakaan (library research). Penelitian kepustakaan ini dimaksudkan untuk mendapatkan data sekunder, berupa bahan-bahan hukum, yang meliputi: bahan hukum primer, yakni peraturan perundang-undangan yang berlaku, antara lain UUD NRI 1945; undang-undang; Peraturan Pemerintah, Peraturan Presiden, Peraturan Mahkamah Agung dan peraturan perundangundangan lain yang terkait dengan judul penelitian; bahan hukum sekunder, yakni bahanbahan hukum yang memberikan penjelasan lebih lanjut dari bahan hukum primer, antara lain doktrin-doktrin, hasil karya ilmiah atau hasil penelitian yang terdapat dalam buku dan jurnal ilmiah, dan berita-berita yang diperoleh dari majalah, surat kabar dan internet; dan bahan hukum tersier, yakni bahan-bahan yang memberikan petunjuk maupun penjelasan terhadap bahan hukum primer dan sekunder seperti kamus hukum, ensiklopedia dan lainlain.

\section{Pengolahan dan Analisa Data}

Penelitian ini menggunakan analisis data deskriptif kualitatif. Teknik analisis data kualitatif adalah cara untuk menganalisis data dengan

17 Bagir Manan, "Penelitian Terapan di Bidang Hukum" (makalah disampaikan pada Lokakarya Peranan Naskah Akademis Dalam Penyusunan Peraturan Perundang-undangan, BPHN, Jakarta, 9-11 November 1993), hlm.7.

18 Soerjono Soekanto dan Sri Mamudji, Penelitian Hukum Normatif: Suatu Tinjauan Singkat (Jakarta: Raja Grafindo Persada, 2001), hlm. 13-14.

19 Abdulkadir Muhammad, Hukum dan Penelitian Hukum (Bandung: Citra Aditya Bakti, 2004), hlm. 132.

20 Soetandyo Wignjosoebroto, Ragam-ragam Penelitian Hukum, dalam Irianto, Sulistyowati dan Shidarta (Ed.). Metode Penelitian Hukum Konstelasi dan Refleksi (Jakarta: Yayasan Pustaka Obor Jakarta, 2011), hlm. 121.

21 J. Supranto, Metode Penelitian Hukum dan Statistik (Jakarta: Rineka Cipta, 2003), hlm. 2. 
mengacu pada norma-norma, asas-asas serta hukum positif yang ada. ${ }^{22}$ Data sekunder yang diperoleh dari studi kepustakaan dianalisa untuk mendapatkan gambaran dan permasalahan berbagai kebijakan dan regulasi dalam bantuan hukum.

\section{Pembahasan}

\section{Konsepsi Bantuan Hukum Yang Selama Ini Terjadi dan Arah Bantuan Hukum Yang Berpihak Pada Masyarakat Miskin}

Di dalam Pasal 27 ayat (1) UUD NRI 1945 ditegaskan bahwa segala warga negara bersamaan kedudukannya di dalam hukum dan pemerintahan dengan tidak ada kecualinya, kemudian di dalam Pasal 28D ayat (1) UUD NRI 1945 ditegaskan pula bahwa setiap orang berhak atas pengakuan, jaminan, perlindungan, dan kepastian hukum yang adil serta perlakuan yang sama di hadapan hukum. Penegasan dalam konstitusi tersebut memberikan makna bahwa di dalam setiap orang melekat hak asasi berupa kedudukan dan perlakuan yang sama di hadapan hukum. Oleh karena sifatnya sebagai suatu hak asasi dan karenanya bersifat universal, maka di dalam Pasal 6-7 Deklarasi Umum Hak Asasi Manusia (DUHAM) ${ }^{23}$ menyatakan setiap orang berhak atas pengakuan sebagai pribadi di depan hukum di mana saja ia berada dan juga semua orang sama di depan hukum dan berhak atas perlindungan hukum yang sama tanpa diskriminasi apapun. Sejalan dengan UUD NRI 1945 dan deklarasi tersebut, di dalam Pasal 17 Undang-Undang Nomor 39 Tahun 1999 tentang Hak Asasi Manusia, ${ }^{24}$ ditegaskan bahwa setiap orang, tanpa diskriminasi, berhak untuk memperoleh keadilan dengan mengajukan permohonan, pengaduan, dan gugatan, baik dalam perkara pidana, perdata, maupun administrasi serta diadili melalui proses peradilan yang bebas dan tidak memihak, sesuai dengan hukum acara yang menjamin pemeriksaan yang obyektif oleh hakim yang jujur dan adil untuk memperoleh putusan yang adil dan benar. Prinsip mempunyai kedudukan yang sama di hadapan pengadilan dan badan peradilan ini pun telah ditegaskan di dalam Pasal 14 (ICCPR), ${ }^{25}$ yang telah diratifikasi melalui Undang-Undang Nomor 12 Tahun 2005 tentang Pengesahan International Covenant on Civil and Political Rights (Konvenan Internasional tentang Hak-Hak Sipil dan Politik). ${ }^{26}$

Berdasarkan penegasan dari UUD NRI 1945, DUHAM, ICCPR serta UU HAM 1999 tersebut di atas, terlihat bahwa Indonesia memberikan

22 Yudha Bhakti Ardhiwisastra, Penafsiran dan Konstruksi Hukum (Bandung: Alumni, 2000), hlm. 8 -12.

23 Ditetapkan oleh Majelis Umum PBB dalam Resolusi 217 A (III) tertanggal 10 Desember 1948.

24 Undang-Undang Nomor 39 Tahun 1999 tentang Hak Asasi Manusia (Lembaran Negara Republik Indonesia Tahun 1999 Nomor 165, Tambahan Lembaran Negara Republik Indonesia Nomor 3886). Untuk selanjutnya dalam tulisan ini disebut "UU HAM 1999".

25 Pada tanggal 16 Desember 1966, dengan resolusi 2200A (XXI), Majelis Umum PBB mengesahkan Kovenan tentang Hak-hak Sipil dan Politik bersama-sama dengan Protokol Opsional pada Kovenan tentang Hak-hak Sipil dan Politik dan Kovenan tentang Hak-hak Ekonomi, Sosial, dan Budaya. Kovenan Internasional tentang Hak-hak Sipil dan Politik beserta Protokol Opsional pada Kovenan Internasional tentang Hak-hak Sipil dan Politik mulai berlaku pada tanggal 23 Maret 1976.

26 Undang-Undang Nomor 12 Tahun 2005 tentang Pengesahan International Covenant on Civil and Political Rights (Konvenan Internasional tentang Hak-Hak Sipil dan Politik), (Lembaran Negara Republik Indonesia Tahun 2005 Nomor 119, Tambahan Lembaran Negara Republik Indonesia Nomor 4558). Untuk selanjutnya dalam tulisan ini disebut "UU ICCPR". 
hak atas jaminan perlakuan yang sama di muka hukum bagi setiap individu, dan bentuk jaminan tersebut salah satunya dikonsepsikan dalam pemberian bantuan hukum secara cuma-cuma bagi orang atau kelompok masyarakat yang kurang mampu atau miskin.

Konkretisasi pemberian bantuan hukum secara cuma-cuma tersebut dalam tataran pengaturan dalam sejarah perkembangannya mengalami derivasi di berbagai peraturan perundang-undangan, sehingga berpengaruh terhadap konsepsi bantuan hukum yang terjadi selama ini.

Di dalam UU Advokat 2003, bantuan hukum dikonsepsikan sebagai jasa hukum yang diberikan oleh advokat secara cuma-cuma kepada klien yang tidak mampu, kemudian di dalam PP Bantuan Hukum 2008 sebagai peraturan pelaksana undang-undang tersebut, mendefinisikan bantuan hukum secara cumacuma, yaitu jasa hukum yang diberikan advokat tanpa menerima pembayaran honorarium meliputi pemberian konsultasi hukum, menjalankan kuasa, mewakili, mendampingi, membela, dan melakukan tindakan hukum lain untuk kepentingan pencari keadilan yang tidak mampu. ${ }^{27}$ Berdasarkan UU Advokat 2003 tersebut, 'pemberi bantuan hukum' dimaknai hanya pada diri advokat semata, dan 'penerima bantuan hukum', dimaknai hanya pada 'klien'nya tidak mampu. Klien ${ }^{28}$ dikonsepsikan oleh Pasal 1 angka (3) UU Advokat 2003 sebagai orang, badan hukum, atau lembaga lain yang menerima jasa hukum dari advokat, sedangkan 'jasa hukum' yang dimaksud adalah jasa yang diberikan advokat berupa memberikan konsultasi hukum, bantuan hukum, menjalankan kuasa, mewakili, mendampingi, membela, dan melakukan tindakan hukum lain untuk kepentingan hukum klien. ${ }^{29}$

Namun, merujuk Pasal 22 UU Advokat 2003, telah terjadi pereduksian makna, yaitu frase 'klien' diubah menjadi frase 'pencari keadilan'. Pereduksian makna ini kembali dipertegas di dalam PP Bantuan Hukum 2008, yaitu dengan mendefinisikan makna 'pencari keadilan' sebagai orang perseorangan atau sekelompok orang yang secara ekonomis tidak mampu yang memerlukan jasa hukum advokat untuk menangani dan menyelesaikan masalah hukum. Pengubahan frase 'klien' menjadi 'pencari keadilan' telah menjadikan makna penerima bantuan hukum tereduksi, artinya bila merujuk pada arti frase 'klien' sebagaimana tersebut di atas, maka seharusnya hubungan yang terjadi antara penerima bantuan hukum dan advokat (pemberi bantuan hukum) adalah hubungan kerja yang profesional dan dalam kedudukan yang sejajar meskipun pemberi bantuan hukum tidak menerima honorarium dan penerima bantuan hukum adalah orang yang tidak mampu. Frase 'pencari keadilan' memberikan konotasi hubungan yang subordinat dan pencari keadilan dalam posisi yang meminta-minta dan memerlukan bantuan hukum kepada advokat. Pembedaan perlakuan pelayanan oleh advokat

27 Garis bawah oleh Penulis.

28 Di dalam Kamus Umum Bahasa Indonesia, klien diartikan sebagai orang yang minta bantuan atau nasihat pada pengacara, konsultan dan sebagainya (W.J.S. Poerwadarminta, Kamus Umum Bahasa Indonesia (Jakarta: Balai Pustaka, 1989), hlm. 513, sedangkan di dalam Black's Law Dictionary, klien atau client didefinisikan sebagai $a$ person or entity that employs a professional for advice or help in that professional's line of work (Bryan A. Garner, Black's Law Dictionary, Op.Cit., hlm. 232). Pengertian di dalam Black's Law memberikan makna pada hubungan kerja yang profesional antara pemberi dan penerima bantuan.

29 Lihat Pasal 1 angka (2) UU Advokat 2003. 
antara klien yang mampu dan tidak mampu secara ekonomi semakin tegas diperlihatkan dalam dalam UU Advokat 2003 maupun Kode Etik Advokat Indonesia, ${ }^{30}$ yaitu dengan adanya frase "jasa hukum" dan "batuan hukum". "Jasa hukum" dimaksudkan untuk klien yang mampu membayar dan "bantuan hukum" dimaksudkan untuk klien yang tidak mampu secara ekonomi. Padahal jelas sekali disebutkan di dalam UU Advokat 2003, bahwa advokat adalah orang yang berprofesi memberi "jasa hukum" dan jasa hukum itu adalah jasa yang diberikan advokat berupa memberikan konsultasi hukum, bantuan hukum, menjalankan kuasa, mewakili, mendampingi, membela, dan melakukan tindakan hukum lain untuk kepentingan hukum klien. Ketidakkonsistenan tersebut secara tidak langsung membawa pengaruh pada perbedaan perlakukan yang diberikan oleh advokat kepada klien yang mampu dan tidak mampu.

Apabila merujuk pada konsepsi bantuan hukum yang ditawarkan oleh UU Advokat 2003 tersebut di atas, maka bantuan hukum yang diberikan dapat dikatakan sebagai bantuan hukum indvidual, atau apabila merujuk pendapat M. Cappellatti dan B. Garth seperti dikutip Abdul Rachman Saleh, dapat dikategorikan pada access to justice gelombang pertama atau dikenal dengan istilah bantuan hukum konvensional, ${ }^{31}$ dimana dasar konsepsi bantuan hukum yang ditawarkan adalah pemberian bantuan hukum kepada masyarakat yang tidak mampu dalam bentuk pendampingan oleh advokat, yang semata-mata hanya dalam proses penyelesaian sengketa saja, yang dihadapi dalam proses peradilan. ${ }^{32}$

Pemaknaan konsepsi bantuan hukum sebagaimana tersebut di atas, diakibatkan perbedaan pendekatan dalam melayani pencari keadilan. Todung Mulya Lubis menyatakan bahwa pendekatan advokat bercirikan: 1) individual; 2) urban (perkotaan); 3) pasif; 4) legalistik; 5) gerakan hukum (legal movemnet); dan 6) persamaan distribusi pelayanan (equal distribution of services), sedangkan pendekatan seorang pembela umum (aktivis legal aid) adalah: 1) struktural (kolektif); 2) urban-rural; 3) aktif; 4) orientasi legal dan non legal; 5) gerakan sosial (social movement); dan 6) perubahan sosial. ${ }^{33}$ Pendekatan yang dianut oleh advokat ini berakibat pada miskinnya kualitas bantuan hukum karena dilakukan tanpa landasan idealisme yang memadai dalam memberikan bantuan hukum secara cuma-cuma. ${ }^{34}$

Pemaknaan konsepsi bantuan hukum secara sempit tersebut dipengaruhi oleh sejarah peraturan perundang-undangan yang secara langsung dan tidak langsung terkait dengan pemberian bantuan hukum. Pada masa sebelum berlakunya hukum acara pidana tahun 1981,

30 Kode Etik Advokat Indonesia yang disahkan pada tanggal 23 Mei 2002 oleh Ikatan Advokat Indonesia (IKADIN) Asosiasi Advokat Indonesia (AAI) Ikatan Penasehat Hukum Indonesia (IPHI) Himpunan Advokat \& Pengacara Indonesia (HAPI) Serikat Pengacara Indonesia (SPI) Asosiasi Konsultan Hukum Indonesia (AKHI) Himpunan Konsultan Hukum Pasar Modal (HKHPM).

31 A.A. Oka Mahendra, "Revitalisasi Bantuan Hukum Dalam Hukum Nasional" http://okamahendra.wordpress. com/ (diakses tanggal 11 Februari 2013).

32 Pusat Studi Hukum dan Kebijakan Indonesia, Advokat Indonesia Mencari Legitimasi, Studi Tentang Tanggung Jawab Profesi Hukum di Indonesia, Op.Cit., hlm. 209.

33 Todung Mulya Lubis, Bantuan Hukum dan Kemiskinan Struktural, Cetakan I (Jakarta: LP3S, 1996), hlm. 60, sebagaimana dikutip dari Pusat Studi Hukum dan Kebijakan Indonesia, Advokat Indonesia Mencari Legitimasi, Studi Tentang Tanggung Jawab Profesi Hukum di Indonesia, Op.Cit., hlm. 212.

34 Frans Hendra Winarta, Bantuan Hukum: Suatu Hak Asasi Manusia Bukan Belas Kasihan, Op.Cit., hlm. 63. 
hukum acara yang berlaku adalah hukum acara yang terdapat di dalam HIR (Herziene Indonesisch Reglement) baik untuk perkara pidana maupun perdata. Dalam perkara perdata HIR tidak mengenal adanya konsep bantuan hukum secara cuma-cuma, namun masih sebatas pembebasan biaya perkara, sedangkan untuk perkara pidana, HIR di dalam Pasal 83-h ayat (6) dan Pasal 250 ayat (5), mengenalkan konsep bantuan hukum hanya terbatas pada mereka yang melakukan kejahatan yang diancam dengan hukuman mati. Sejak diberlakukannya Undang-Undang Nomor 8 Tahun 1981 tentang Ketentuan Hukum Acara Pidana (KUHAP), ketentuan konsep bantuan hukum yang terdapat di HIR diubah total dan lebih menghormati hak tersangka/terdakwa. Pasal 56 KUHAP mewajibkan pejabat yang berwenang pada setiap tingkat pemeriksaan untuk menunjuk penasehat hukum bagi tersangka/terdakwa yang diancam pidana mati atau pidana penjara 15 tahun atau lebih; dan bagi mereka yang tidak mampu yang diancam penjara pidana 5 tahun atau lebih. ${ }^{35}$

Pengaturan bantuan hukum lainnya diatur secara parsial dan tidak merupakan suatu sistem yang saling kait-mengkait antara satu peraturan dengan peraturan yang lain sehingga tidak terciptanya suatu kesinkronan dalam pemberian bantuan hukum. Pengaturan pemberian bantuan hukum antara lain di atur di dalam Undang-Undang Nomor 48 Tahun 2009 tentang Kekuasaan Kehakiman; ${ }^{36}$ Undang-Undang Nomor 49 Tahun 2009 tentang Perubahan Kedua Atas Undang-Undang Nomor 2 Tahun 1986 tentang Peradilan Umum; ${ }^{37}$ Undang-Undang Nomor 50 Tahun 2009 tentang Perubahan Kedua Atas Undang-Undang Nomor 7 Tahun 1989 tentang Peradilan Agama; 38 dan Undang-Undang Nomor 51 Tahun 2009 Tentang Perubahan Kedua Atas Undang-Undang Nomor 5 Tahun 1986 Tentang Peradilan Tata Usaha Negara. ${ }^{39}$ Keempat undang-undang tersebut memiliki konsepsi yang sama tentang bantuan hukum, yaitu bahwa setiap orang yang tersangkut perkara berhak memperoleh bantuan hukum dengan membentuk Pos Bantuan Hukum (Posbakum) disetiap peradilan umum, peradilan agama dan peradilan tata usaha negara. ${ }^{40}$ Konsepsi bantuan hukum yang diberikan oleh keempat undangundang tersebut dapat dikatakan masih sebagai bantuan hukum indvidual atau konvesional yaitu pemberian bantuan hukum kepada masyarakat tidak mampu dalam bentuk pendampingan oleh advokat, yang semata-mata hanya dalam proses

35 Pusat Studi Hukum dan Kebijakan Indonesia, Advokat Indonesia Mencari Legitimasi, Studi Tentang Tanggung Jawab Profesi Hukum di Indonesia, Op.Cit., hlm. 223.

36 Undang-Undang Nomor 48 Tahun 2009 tentang Kekuasaan Kehakiman (Lembaran Negara Republik Indonesia Tahun 2009 Nomor 157, Tambahan Lembaran Negara Republik Indonesia Nomor 5076). Untuk selanjutnya di dalam tulisan ini disebut "UU Kehakiman 2009").

37 Undang-Undang Republik Indonesia Nomor 49 Tahun 2009 tentang Perubahan Kedua Atas Undang-Undang Nomor 2 Tahun 1986 tentang Peradilan Umum (Lembaran Negara Republik Indonesia Tahun 2009 Nomor 158, Tambahan Lembaran Negara Republik Indonesia Nomor 5077).

38 Undang-Undang Republik Indonesia Nomor 50 Tahun 2009 tentang Perubahan Kedua Atas Undang-Undang Nomor 7 Tahun 1989 tentang Peradilan Agama (Lembaran Negara Republik Indonesia Tahun 2009 Nomor 159, Tambahan Lembaran Negara Republik Indonesia Nomor 5078).

39 Undang-Undang Republik Indonesia Nomor 51 Tahun 2009 Tentang Perubahan Kedua Atas Undang-Undang Nomor 5 Tahun 1986 Tentang Peradilan Tata Usaha Negara (Lembaran Negara Republik Indonesia Tahun 2009 Nomor 160, Tambahan Lembaran Negara Republik Indonesia Nomor 5079).

40 Pelaksanaan keempat undang-undang tersebut diatur di dalam Surat Edaran Mahkamah Agung Nomor 10 Tahun 2010 tentang Pedoman Pemberian Bantuan Hukum. 
penyelesaian sengketa saja, yang dihadapi dalam proses peradilan.

Bentukbantuanhukumyangjuga diatursecara parsial dan masih dalam bentuk konsep bantuan hukum individual dan konvensional dapat dilihat dalam Pasal 17 dan 18 Undang-Undang Nomor 23 Tahun 2002 tentang Perlindungan Anak, yaitu setiap anak yang dirampas kebebasannya dan setiap anak yang menjadi korban atau pelaku tindak pidana berhak untuk memperoleh bantuan hukum atau bantuan lainnya secara efektif dalam setiap tahapan upaya hukum yang berlaku. Kemudian di Pasal 11 Undang-Undang Nomor 23 Tahun 2004 tentang Penghapusan Kekerasan Dalam Rumah Tangga disebutkan bahwa korban yang mengalami kekerasan dan/ atau ancaman kekerasan dalam lingkup rumah berhak mendapatkan pendampingan oleh pekerja sosial dan bantuan hukum pada setiap tingkat proses pemeriksaan sesuai dengan ketentuan peraturan perundang-undangan. Konsep bantuan hukum juga diatur dalam Pasal 80 Undang-Undang Nomor 39 Tahun 2004 tentang Penempatan dan Perlindungan Tenaga Kerja Indonesia di Luar Negeri, yaitu dengan pemberian bantuan hukum kepada tenaga kerja Indonesia sesuai dengan ketentuan peraturan perundang-undangan di negara tujuan serta hukum dan kebiasaan internasional selama masa penempatan di luar negeri.

Konsepsi bantuan hukum yang terjadi selama ini masih bersifat individual dan konvesional dengan pengaturan yang bersifat parsial dan tidak tersistem membawa pada suatu kondisi belum terwujudnya suatu perubahan sosial yang berkeadilan dan kesadaran hukum masyarakat serta mudahnya akses untuk mendapatkan keadilan tersebut.

Berkaca pada kondisi tersebut dan juga dalam rangka untuk mewujudkan negara hukum yang mengakui dan melindungi serta menjamin hak asasi warga negara akan kebutuhan akses terhadap keadilan (access to justice) dan kesamaan di hadapan hukum (equality before the law), maka peran negara hadir dalam membentuk regulasi dalam bentuk UU Bantuan Hukum 2011.

UU Bantuan Hukum 2011 memberikan suatu konsep baru bantuan hukum, yaitu bahwa bantuan hukum selain bertujuan untuk menjamin dan memenuhi hak bagi orang atau kelompok miskin untuk mendapatkan akses keadilan juga untuk mewujudkan kepastian penyelenggaraan bantuan hukum dapat dilaksanakan secara merata di seluruh wilayah Negara Republik Indonesia dan mewujudkan peradilan yang efektif, efisien, dan dapat dipertanggungjawabkan. Konkretisasi konsep tersebut diimplementasikan dalam berbagai bentuk antara lain memberikan bantuan hukum kepada orang atau kelompok miskin yang menghadapi masalah hukum baik perdata, pidana, maupun tata usaha negara, baik litigasi maupun nonlitigasi; dan juga menyelenggarakan penyuluhan hukum, konsultasi hukum, dan program kegiatan lain yang berkaitan dengan penyelenggaraan Bantuan Hukum, yaitu investigasi kasus, pendokumentasian hukum, penelitian hukum, mediasi, negosiasi, dan pemberdayaan masyarakat.

Melihat konsepsi bantuan hukum yang diintroduksioleh UU Bantuan Hukum 2011, maka bantuan hukum yang dimaksud bukan sematamata proses penyelesaian sengketa saja, yang dihadapi dalam proses peradilan, namun juga ada suatu upaya untuk menciptakan kemudahan dan pemerataan akses bantuan hukum dan juga ada bentuk penyuluhan hukum, konsultasi hukum, penelitian hukum dan pemberdayaan masyarakat. 
Konsep bantuan hukum dalam UU Bantuan Hukum 2011 dan turut sertanya negara dalam penyelenggaraan bantuan hukum, sejalan dengan apa yang dinyatakan oleh Cappelletti dan Gordley dalam artikel yang berjudul "Legal aid: modern themes and variations", yaitu pada dasarnya terdapat dua model (sistem) bantuan hukum, yaitu 'model yuridis-individual' dan 'model kesejahteraan', artinya bantuan hukum dapat dilihat sebagai suatu hak yang diberikan kepada warga masyarakat untuk melindungi kepentingan-kepentingan individual, dan di lain pihak sebagai suatu hak akan kesejahteraan yang menjadi bagian dari kerangka perlindungan sosial yang diberikan suatu negara kesejahteraan. Model yuridis-individual adalah ciri pola klasik dari bantuan hukum, artinya permintaan akan bantuan hukum tergantung pada masyarakat yang membutuhkan. Sedangkan model kesejahteraan, memandang bantuan hukum sebagai bagian dari haluan sosial, misalnya untuk menetralisasikan ketidakpastian atau kemiskinan. Peran negara untuk ikut campur diperlukan dalam model kesejahteraan, untuk memenuhi kebutuhan dasar warga masyarakat dan bantuan hukum sebagai salah satu cara untuk memenuhi kebutuhan itu. Sehingga ruang lingkup dalam model kesejahteraan ini lebih luas, hal ini karena bantuan hukum menjadi bagian dari program pengembangan sosial atau perbaikan sosial. ${ }^{41}$ Dengan diberlakukannya UU Bantuan Hukum 2011, maka negara dalam hal ini telah ikut campur dengan program-program yang bukan hanya penyelesaian masalah hukum namun juga program pemberdayaan masyarakat.
Model bantuan hukum dalam bentuk penyuluhan hukum, konsultasi hukum, dan penelitian hukum sejalan pula dengan apa yang dikatakan oleh Groenendijk dan Sloot, yaitu bahwa penyuluhan hukum merupakan bentuk 'bantuan hukum preventif', yang bertujuan agar masyarakat mengerti hak dan kewajibannya sebagai warga negara. Konsultasi hukum merupakan bentuk 'bantuan hukum diagnostik', yaitu berupa pemberian nasehat hukum, sedangkan penelitian hukum merupakan bentuk 'bantuan hukum pembentukan dan pembaruan hukum', yaitu bantuan hukum yang usaha-usahanya lebih ditujukan mengadakan pembaruan hukum melalui pembentukan undang-undang dalam arti materiil. ${ }^{42}$

Arah bantuan hukum di Indonesia ke depannya diharapkan mempunyai tujuan dan ruang lingkup yang lebih luas dari yang telah di tawarkan oleh UU Bantuan Hukum 2011, yaitu tidak hanya sekedar proses penyelesaian sengketa dalam proses peradilan, namun juga meningkatkan kesadaran hukum dan membangun masyarakat yang cerdas hukum yang mengerti akan pentingnya hukum. Adnan Buyung Nasution mengungkapkan, diperlukan bantuan hukum melalui pendidikan masyarakat untuk menumbuhkan dan membina kesadaran akan hak-hak sebagai subjek hukum. ${ }^{43}$

\section{Sinergitas Peran Negara dan Advokat Dalam Pemberian Bantuan Hukum Cuma-Cuma}

Advokat adalah orang yang berprofesi memberikan jasa hukum, baik di dalam 
maupun di luar pengadilan, ${ }^{44}$ dan bertugas menyelesaikan persoalan hukum kliennya baik secara litigasi maupun nonlitigasi, dan sejak dulu keberadaan advokat selalu ada semacam ambivalensi. Dalam bahasanya Frans Hendra Winata, tugas advokat adalah mengabdikan dirinya pada masyarakat sehingga dia dituntut untuk selalu turut serta dalam penegakan hak asasi manusia, dan dalam menjalankan profesinya ia bebas untuk membela siapapun, tidak terikat pada perintah (order) klien dan tidak pandang bulu siapa lawan kliennya, apakah dia dari golongan kuat, penguasa, pejabat bahkan rakyat miskin sekalipun. Salah satu hal lain yang menarik perhatian adalah peran advokat bukan hanya sebagai spesialisasi dalam penyelesaian pertentangan antara warga, tapi juga sebagai spesialisasi dalam hubungan antara warga negara dan lembaga-lembaga pemerintahan, yaitu antara masyarakat dan negara. Dalam negara modern, tanpa ada orang yang mengisi fungsi itu secara profesional, masyarakat akan lebih mudah ditindas dan dipermainkan oleh penguasa. Fungsi advokat bukan hanya berperkara di pengadilan, namun sangat penting, mewakili kepentingan warga negara dalam hubungannya dengan pemerintah. Justru karena profesi advokat mengerti akan bentuk, lembaga dan aturan negara dan bertugas untuk mewakili warga negara kalau bertentangan dengan negara atau warga negara yang lainnya. Dalam kondisi yang demikian banyak advokat dengan sendirinya muncul dalam politik, urusan sosial, pendidikan, perjuangan perubahan politik atau ekonomi, dan sering masuk menjadi pimpinan gerakan reformasi. Bukan hanya advokat tentunya, tapi profesi itu menonjol dalam sejarah negara modern sebagai sumber ide dan perjuangan modernisasi, keadilan, hak asasi manusia, konstitusionalisme dan sejenisnya. ${ }^{45}$

Sejarah di Indonesia menunjukkan kontribusi signifikan dari kalangan advokat terhadap pelaksanaân bantuan hukum cumacuma. Lembaga-lembaga bantuan hukum yang kini tumbuh di Indonesia tidak lepas dari peran advokat, bahkan organisasi advokat pun secara terbatas menjadikan bantuan hukum cuma-cuma sebagai tolak ukur keberhasilan program pengabdiannya pada masyarakat. Namun latar belakang bantuan hukum cumacuma yang mereka berikan, sebagian besar dilatarbelakangi oleh sikap kedermawanan (charity), yaitu atas dasar tanggung jawab moral dan kemanusiaan, sehingga hanya sedikit advokat yang mendasar kegiatannya tersebut pada tujuan yang lebih besar, yaitu fair trial. Hal ini yang menyebabkan proses pelembagaan bantuan hukum berjalan sedemikian tersendat dan tidak kunjung mendatangkan harapan untuk bisa menjadikannya sebagai gerakan kolektif serta rendahnya kualitas jasa hukum yang diberikan. ${ }^{46}$

Permasalahan klasik lainnya adalah masalah pendanaan. Lembaga-lembaga bantuan hukum yang ada pada umumnya mencari dana sendiri guna membiayai operasionalnya, sehingga hal ini berpengaruh langsung terhadap

\footnotetext{
44 Lihat Pasal 1 angka (1) UU Advokat 2003.

45 Teguh Adminto, Peran Advokat Dalam Penegakan Hukum Mengenai Implementasi Penanganan Kasus Pro-Bono (Prodeo), http://tittoarema.blogspot.com/2005/12/peran-advokat-dalam-penegakan-hukum.html, (diakses tanggal 8 Februari 2013).

46 Pusat Studi Hukum dan Kebijakan Indonesia, Advokat Indonesia Mencari Legitimasi, Studi Tentang Tanggung Jawab Profesi Hukum di Indonesia, Op.Cit., hlm. 234-242.
} 
keberlangsungan bantuan hukum yang diberikan.

Pesebaran jumlah advokat yang tidak merata di seluruh pelosok dan hanya banyak terdapat di kota-kota besar, menjadi permasalahan tersendiri dalam terdapatnya akses bagi masyarakat untuk mencari keadilan.

Upaya campur tangan negara dalam mengatasi permasalahan yang melanda advokat dalam memberikan bantuan hukum secara cuma-cuma sejatinya telah diakomodir dengan dikeluarkannya PP Bantuan Hukum 2008 dan Surat Edaran Mahkamah Agung Nomor 10 Tahun 2010 tentang Pedoman Pemberian Bantuan Hukum, namun upaya ini merupakan suatu upaya injeksi sesaat dan hanya mampu mengatasi model bantuan hukum secara individual dan konvensional, sehingga dalam mewujudkan bantuan hukum dengan model kesejahteraan akan berjalan tersendat.

Dengan diberlakukannya UU Bantuan Hukum 2011, peran negara dalam mewujudkan model bantuan hukum kesejahteraan akan relatif mudah tercapai. Secara filosofis, menurut Wicipto Setiadi, UU Bantuan Hukum dapat dimaknai dalam konteks memperluas akses masyarakat terhadap keadilan dan hal ini memudahkan orang miskin mengakses hukum dan keadilan. ${ }^{47}$

Permasalahan pesebaran jumlah advokat yang tidak merata di seluruh pelosok tanah air, sehingga akses masyarakat untuk mencari keadilan terhambat setidaknya dapat diatasi dengan diakuinya peran paralegal, dosen dan mahasiswa fakultas hukum dalam melakukan pelayanan hukum secara cuma-cuma. ${ }^{48}$
Diakuinya paralegal, dosen dan mahasiswa fakultas hukum oleh UU Bantuan Hukum 2011 memberi peluang untuk dapat beracara dalam proses peradilan, sehingga sejalan dengantujuan Pasal 3 huruf c UU Bantuan Hukum 2011, yaitu penyelenggaraan bantuan hukum bertujuan untuk menjamin kepastian penyelenggaraan bantuan hukum dilaksanakan secara merata di seluruh wilayah Negara Kesatuan Republik Indonesia.

Gerakan advokat yang masih bersifat individual dan bukan suatu gerakan kolektif menjadikan rendahnya kualitas bantuan hukum yang dihasilkan, oleh karena itu di dalam UU Bantuan Hukum 2011, objek yang diatur sebagai pemberi bantuan hukum adalah lembaga bantuan hukum atau organisasi kemasyarakatan, sehingga bersifat kelembagaan dan kolektif dan bukan gerakan individual advokat sehingga perannya dalam memberikan bantuan dan mengeluarkan pendapat atau pernyataan dalam membela perkara yang menjadi tanggung jawabnya di dalam sidang pengadilan hukum dapat lebih maksimal.

Namun dengan diberlakukannya UU Bantuan Hukum 2011 bukan berarti kewajiban advokat dalam memberikan bantuan hukum terhapuskan. Di dalam penjelasan Pasal 6 ayat (2) UU Bantuan Hukum 2011 ditegaskan bahwa pelaksanaan bantuan hukum oleh pemberi bantuan hukum ini tidak mengurangi kewajiban profesi Advokat untuk menyelenggarakan bantuan hukum berdasarkan UU Advokat 2003.

Peran negara dengan diberlakukannya UU Bantuan Hukum 2011 justru menguatkan peran advokat dalam memberikan bantuan

\footnotetext{
47 http://www.hukumonline.com/berita/baca/lt506ba85e68bd1/ylbhi-akan-intervensi-pengujian-uu-bantuanhukum (diakses tanggal 13Maret 2013).
}

48 Lihat Pasal 9 UU Bantuan Hukum 2011. 
cuma-cuma, sehingga peran dan kewajiban advokat yang diatur dalam UU Advokat 2003 dapat bersinergi dengan peran negara dalam menyelenggarakan bantuan hukum sebagaimana diatur dalam UU Bantuan Hukum 2011.

\section{E. Penutup}

Konsepsi bantuan hukum yang terjadi selama ini yang bersifat individual dan konvesional dengan pengaturan yang bersifat parsial dan tidak tersistem membawa pada suatu kondisi belum terwujudnya suatu perubahan sosial yang berkeadilan dan kesadaran hukum masyarakat serta mudahnya akses untuk mendapatkan keadilan tersebut. Berkaca pada kondisi tersebut dan juga dalam rangka mewujudkan negara hukum yang mengakui dan melindungi serta menjamin hak asasi warga negara akan kebutuhan akses terhadap keadilan (access to justice) dan kesamaan di hadapan hukum (equality before the law), maka peran negara hadir dalam membentuk regulasi dalam bentuk UU Bantuan Hukum 2011, yang memberikan suatu konsep baru bantuan hukum, yaitu bahwa bantuan hukum selain bertujuan untuk menjamin dan memenuhi hak bagi orang atau kelompok miskin untuk mendapatkan akses keadilan juga untuk mewujudkan kepastian penyelenggaraan bantuan hukum dapat dilaksanakan secara merata di seluruh wilayah Negara Republik Indonesia dan mewujudkan peradilan yang efektif, efisien, dan dapat dipertanggungjawabkan. Konsep bantuan hukum tersebut sejalan model (sistem) bantuan hukum kesejahteraan', artinya bantuan hukum dapat dilihat sebagai suatu hak yang diberikan kepada warga masyarakat untuk melindungi kepentingan-kepentingan individual, dan di lain pihak sebagai suatu hak akan kesejahteraan yang menjadibagian darikerangka perlindungan sosial yang diberikan suatu negara kesejahteraan.

Kewajiban advokat dalam memberikan bantuan yang dilatarbelakangi oleh sikap kedermawanan (charity) dan sebagai suatu gerakan individual menjadikan rendahnya kualitas jasa hukum yang diberikan. Selain itu masalah pendanaan; pesebaran jumlah advokat yang tidak merata di seluruh pelosok menjadi penghambat dalam jaminan akses masyarakat dalam mencari keadilan, sehingga dengan diberlakukannya UU Bantuan Hukum 2011, peran negara dalam mewujudkan model bantuan hukum kesejahteraan akan relatif mudah tercapai. Permasalahan gerakan advokat yang masih bersifat individual terakomodir di dalam UU Bantuan Hukum 2011, karena objek yang diatur sebagai pemberi bantuan hukum adalah lembaga bantuan hukum atau organisasi kemasyarakatan, sehingga bersifat kelembagaan dan kolektif.

Berlakunya UU Bantuan Hukum 2011 bukan berarti kewajiban advokat dalam memberikan bantuan hukum terhapuskan, melainkan dengan diberlakukannya UU Bantuan Hukum 2011 justru menguatkan peran advokat dalam memberikan bantuan cuma-cuma, sehingga peran dan kewajiban advokat yang diatur dalam UU Advokat 2003 dapat bersinergi dengan peran negara dalam menyelenggarakan bantuan hukum sebagaimana diatur dalam UU Bantuan Hukum 2011.

\section{DAFTAR PUSTAKA}

\section{Buku}

Ardhiwisastra, Yudha Bhakti, Penafsiran dan Konstruksi Hukum (Bandung: Alumni, 2000).

Garner, Bryan A., Black's Law Dictionary, Abridged $9^{\text {th }}$ Edition (St. Paul, MN: Thomson Reuters, 2010). 
Lubis, Todung Mulya, Bantuan Hukum dan Kemiskinan Struktural, Cetakan I (Jakarta: LP3S, 1996).

Lubis, Todung Mulya, Catatan Hukum Todung Mulya Lubis, Mengapa Saya Mencintai Negeri Ini?, (Jakarta: Kompas Media Nusantara, 2008).

Muhammad, Abdulkadir, Hukum dan Penelitian Hukum (Bandung: Citra Aditya Bakti, 2004).

Pangaribuan, Luhut M.P., Advokat dan Contempt of Court, Suatu Proses di Dewan Kehormatan Profesi (Jakarta: Djambatan: 2002).

Poerwadarminta, W.J.S., Kamus Umum Bahasa Indonesia (Jakarta: Balai Pustaka, 1989).

Pusat Studi Hukum dan Kebijakan Indonesia, Advokat Indonesia Mencari Legitimasi, Studi Tentang Tanggung Jawab Profesi Hukum di Indonesia (Jakarta: PSHK, 2001).

Rahardjo, Satjipto, Penegakan Hukum Progresif (Jakarta, Penerbit Buku Kompas, 2010).

Soekanto, Soerjono dan Sri Mamudji, Penelitian Hukum Normatif: Suatu Tinjauan Singkat (Jakarta: Raja Grafindo Persada, 2001).

Soekanto, Soerjono, Bantuan Hukum Suatu Tinjauan Sosio Yuridis (Jakarta: Ghalia Indonesia, 1983).

Supranto, J., Metode Penelitian Hukum dan Statistik (Jakarta: Rineka Cipta, 2003).

Wignjosoebroto, Soetandyo, Ragam-ragam Penelitian Hukum, dalam Irianto, Sulistyowati dan Shidarta (Ed.). Metode Penelitian Hukum Konstelasi dan Refleksi (Jakarta: Yayasan Pustaka Obor Jakarta, 2011).

Winarta, Frans Hendra, Bantuan Hukum: Suatu Hak Asasi Manusia Bukan Belas Kasihan (Jakarta: Elex Media Komputindo, 2000).

\section{Makalah / Artikel / Prosiding / Hasil Penelitian}

Manan, Bagir, "Penelitian Terapan di Bidang Hukum", (makalah, disampaikan pada Lokakarya Peranan Naskah Akademis Dalam Penyusunan Peraturan Perundang-undangan, BPHN, Jakarta, 9 - 11 November 1993).

\section{Internet}

Adminto, Teguh, Peran Advokat Dalam Penegakan Hukum Mengenai Implementasi Penanganan Kasus Pro-Bono (Prodeo), http://tittoarema. blogspot.com/2005/12/peran-advokat-dalampenegakan-hukum.html.

Anggara, "Organisasi Advokat dan Program Bantuan Hukum di Indonesia", http://anggara. org/2011/04/12/organisasi-advokat-danprogram-bantuan-hukum-di-indonesia/.

http://www.hukumonline.com/berita/baca/ It506ba85e68bd1/ylbhi-akan-intervensipengujian-uu-bantuan-hukum.

Mahendra, A.A. Oka, "Revitalisasi Bantuan Hukum Dalam Hukum Nasional" http://okamahendra. wordpress.com/.

Winarta, Frans Hendra, "Paradigma Bantuan Hukum Sekarang Harus Banting Setir," www. hukumonline.com.

\section{Peraturan}

Undang-Undang Dasar Negara Republik Indonesia Tahun 1945.

Undang-Undang Nomor 18 Tahun 2003 tentang Advokat (Lembaran Negara Republik Indonesia Tahun 2003 Nomor 49, Tambahan Lembaran Negara Republik Indonesia Nomor 4288).

Undang-Undang Nomor 16 Tahun 2011 tentang Bantuan Hukum (Lembaran Negara Republik Indonesia Tahun 2011 Nomor 104, Tambahan Lembaran Negara Republik Indonesia Nomor 5248).

Undang-Undang Nomor 14 Tahun 1970 tentang Ketentuan Pokok Kekuasaan Kehakiman.

Undang-Undang Nomor 2 Tahun 1986 tentang Peradilan Umum.

Undang-Undang Nomor 39 Tahun 1999 tentang Hak Asasi Manusia (Lembaran Negara Republik Indonesia Tahun 1999 Nomor 165, Tambahan Lembaran Negara Republik Indonesia Nomor 3886).

Undang-Undang Nomor 12 Tahun 2005 tentang Pengesahan International Covenant on Civil and Political Rights (Konvenan Internasional tentang Hak-Hak Sipil dan Politik), (Lembaran Negara Republik Indonesia Tahun 2005 Nomor 119, Tambahan Lembaran Negara Republik Indonesia Nomor 4558).

Undang-Undang Nomor 48 Tahun 2009 tentang Kekuasaan Kehakiman (Lembaran Negara Republik Indonesia Tahun 2009 Nomor 157, Tambahan Lembaran Negara Republik Indonesia Nomor 5076).

Undang-Undang Republik Indonesia Nomor 49 Tahun 2009 tentang Perubahan Kedua Atas Undang-Undang Nomor 2 Tahun 1986 tentang Peradilan Umum (Lembaran Negara Republik Indonesia Tahun 2009 Nomor 158, Tambahan 


\section{REECHTSVINDING

Lembaran Negara Republik Indonesia Nomor 5077).

Undang-Undang Republik Indonesia Nomor 50 Tahun 2009 tentang Perubahan Kedua Atas Undang-Undang Nomor 7 Tahun 1989 tentang Peradilan Agama (Lembaran Negara Republik Indonesia Tahun 2009 Nomor 159, Tambahan Lembaran Negara Republik Indonesia Nomor 5078).

Undang-Undang Republik Indonesia Nomor 51 Tahun 2009 Tentang Perubahan Kedua Atas Undang-Undang Nomor 5 Tahun 1986 Tentang Peradilan Tata Usaha Negara (Lembaran Negara Republik Indonesia Tahun 2009 Nomor 160,
Tambahan Lembaran Negara Republik Indonesia Nomor 5079).

Peraturan Pemerintah Nomor 83 Tahun 2008 tentang Persyaratan dan Tata Cara Pemberian Bantuan Hukum Secara Cuma-Cuma.

Peraturan Presiden Nomor 5 Tahun 2010 tentang Rencana Pembangunan Menengah Nasional (RPJMN) Tahun 2010-2014.

Surat Edaran Mahkamah Agung Nomor 10 tahun 2010 tentang Pedoman Pemberian Bantuan Hukum.

Kode Etik Advokat Indonesia. 